\title{
A recombinant attenuated candidate vaccine that efficiently and persistently protects against bovine leukemia virus in herds
}

\author{
Sabrina M Rodríguez ${ }^{1,2^{*}}$, Gerónimo Gutiérrez ${ }^{3}$, Nicolas Gillet ${ }^{1}$, Karina Trono ${ }^{3}$, Luc Willems ${ }^{1,2}$ \\ From 16th International Conference on Human Retroviruses: HTLV and Related Viruses \\ Montreal, Canada. 26-30 June 2013
}

There currently is no efficient vaccine that protects against bovine leukemia virus (BLV) infection. We now propose a novel approach based on the use of a recombinant live-attenuated BLV provirus. The rationale behind this strategy relies on the deletion of genes required to induce pathogenesis maintaining the integrity of those involved in infectivity. We have identified a BLV attenuated provirus that is infectious but replicates at reduced levels in cattle. The attenuated strain elicits a strong antiBLV immune response and does not spread to uninfected sentinels maintained during 3 years in the same herd supporting biosafety of the vaccine. Passive antibodies are transmitted to newborn calves via maternal colostrum and persist during several months. Nevertheless, the BLV attenuated provirus does not transmit from cows to calves. Finally, vaccinated animals resist challenge by a wild-type BLV virus. In summary, we have identified a safe BLV attenuated provirus with impaired transmissibility that efficiently protects against infection in herd conditions.

\section{Authors' details}

${ }^{1}$ Molecular and Cellular Epigenetics, Interdisciplinary Cluster for Applied Genoproteomics (GIGA), University of Liège (ULg), Liège, Belgium. ${ }^{2}$ Molecular and Cellular Biology, Gembloux Agro-Bio Tech, University of Liège (ULg), Gembloux, Belgium. Instituto de Virología, CICVyA, Instituto Nacional de Tecnología Agropecuaria, Castelar, Argentina.

Published: 7 January 2014
doi:10.1186/1742-4690-11-S1-010

Cite this article as: Rodríguez et al:: A recombinant attenuated candidate vaccine that efficiently and persistently protects against bovine leukemia virus in herds. Retrovirology 2014 11(Suppl 1):010.

\footnotetext{
* Correspondence: sabrina.rodriguez@ulg.ac.be

${ }^{1}$ Molecular and Cellular Epigenetics, Interdisciplinary Cluster for Applied

Genoproteomics (GIGA), University of Liège (ULg), Liège, Belgium
}

Full list of author information is available at the end of the article

Submit your next manuscript to BioMed Central and take full advantage of:

- Convenient online submission

- Thorough peer review

- No space constraints or color figure charges

- Immediate publication on acceptance

- Inclusion in PubMed, CAS, Scopus and Google Scholar

- Research which is freely available for redistribution

Submit your manuscript at www.biomedcentral.com/submit
() Biomed Central 